\title{
Sovereign grace and human freedom
}

\author{
HISTORICAL BACKGROUND
}

Philip Schaaf, a distinguished church historian of a past generation, once called the debate about God's sovereignty and human freedom "the question of the ages." That may not be so for everyone, but with the church it remains a question that will not go away. What the late Albert Outler wrote in 1975 is amazingly relevant today.

'In our day when all the great traditions that have held the world together for centuries (however tenuously) are suddenly becoming frazzled and "inoperative" the issue between human self-sufficiency and God's primacy is still the great dividing line in all our struggles for a theology of culture that is actually theo-logy and not some sort of religious anthro-pology writ large across a cosmic backdrop. All our most fashionable credos today (the new a-morality, the new secularism, the new emotionalism and "supernaturalisms" - ESP, psychokinesis, "transcendental meditation," TA, and others) are all fresh variations on the old themes of human autonomy: viz., the conviction that human beings can and must accept final responsibility for their own well-being and their collective destinies.' ${ }^{1}$

\section{AUGUSTINE AND AQUINAS}

It all began with Augustine's famous debate with Pelagius about the freedom of the will. That is, are sinners able to choose rightly without the assistance of God's grace? Augustine's analysis of the doctrine of grace was a turning point in the theology of the early church. The early church fathers generally taught that the reception of God's mercy and grace was to some extent dependent on an individual's response. ${ }^{2}$ Augustine concluded that human merit plays no part in our salvation and that God's grace is utterly gratuitous. However, in his early writings Augustine conceded that to some extent humans must respond to God's gracious initiative by cooperating with God's grace. ${ }^{3}$ However, once he was attacked by Pelagius, Augustine clarified his position concerning the bondage and freedom of the will. In De spiritu et littera (The Spirit and the Letter), written in 412, Augustine clarifies his views on sin, grace, and the freedom of the will in response to Pelagius's misuse of certain passages in Augustine's earlier writings. He came to see that a radical view of sin requires a radical view of grace and that our salvation from beginning to end is a work of God's grace. Key texts for him in his later writings were John 15:5; Romans 9:1 Corinthians 4:7; and Philippians 2:13.

'The effect of the Pelagian controversy was to sharpen the dilemma-either God's work or ours. That the dilemma is false, Augustine himself was able in his old age to recognize on occasion.' ${ }^{4}$ This, as I will point out later, is what I believe any helpful and biblically balanced view of this issue must affirm, viz., that it is not a matter of either/or but rather both/and. Unfortunately, most of the later discussions of this issue have been so polemical that it appeared that one must magnify the sovereign grace of God (or election) at the expense of human responsibility and meaningful participation; or that in order to do justice to human freedom one must undercut 
the radical work of God's grace in the process of salvation.

Augustine's solution to this problem has never won universal acceptance. The Roman Church of his time officially condemned the Pelagians, but it did not accept the corollary of Augustine's doctrine of grace, viz., predestination, nor his view that the will is unable to do what is good until freed by God's grace and the enabling work of the Spirit. A modified Augustinianism became the official position of the church after the Synod of Orange (529), which met exactly 100 years after Augustine's death. However, in the early medieval period his theology of sin and grace was already watered down. A key figure here is Pope Gregory (elected in 590) who had a long and influential reign. He ostensibly taught Augustinianism in a simplified form but his position was synergistic. That is, our salvation consists of a cooperation between God's grace and our free will, a position that was denounced by Luther in the sixteenth century. Eventually, in the late medieval period an "Augustinian synthesis" ended up with an unhappy compromise, viz., that "we ought to believe both the grace of God and the free will of man," neither without the other. ${ }^{5}$ The problem is that it was never clarified as in what sense the sinful human will is free. Even the "angelic doctor," Thomas Aquinas, did not do much to clarify the situation. Prior to Aquinas something of a consensus had developed, viz., that the paradox of divine sovereignty and human free will can be resolved in terms of God's foreknowledge. That foreknowledge, in turn, was explained on the basis of there being no past, present, or future in God-only an eternal present. This includes even future contingencies. We only know them successively; God knows them simultaneously, according to Albertus, Aquinas's mentor. ${ }^{6}$

This doesn't really help very much. Aquinas, therefore, saw the necessity of moving beyond a simple appeal to God's eternity and foreknowledge. In regard to the question of the will Aquinas entertains various objections that the will is not free. He cites texts such as Romans 7:19, 9:16, and Philippians 2:13 to support this contention. But he replies: "Man has free will; otherwise counsels, exhortations, commands, prohibitions, rewards, and punishments would be in vain." 7 Peter Kreeft, the popular Roman Catholic scholar, makes the following observation concerning this passage: "Note how basic, practical, and commonsensical St. Thomas' first argument is. Note how he connects free will with reason." ${ }^{\prime}$ I am not as enthusiastic about this "solution" because of the role reason plays here. Aquinas goes on to say, "Forasmuch as man is rational it is necessary that man have a free-will?" 9

Fortunately, this is not the end of the matter. Although Aquinas seems to ignore the texts cited by his hypothetical objector, he does take note of Romans 7:19: "The good which I will I do not..." Aquinas then adds, "Those words of the Apostle are not to be taken as though man does not wish or does not run of his free-will, but because the free-will is not sufficient thereto unless it be moved and helped by God"10 (emphasis mine). Thus, for Aquinas free will is not what it was for Pelagius or today's secular humanists, for though "free-will is the cause of its own movement," behind it is God who is the first cause, who moves both natural and voluntary." 11

Kreeft again finds here a "simple and elegant" solution to "the thorny problem of reconciling human free will with divine causality"-Grace, he adds, in Aquinas "establishes nature rather than removing it." ${ }^{12}$ Whether this represents an advance on Augustine is doubtful. The Protestant historian, William Cannon, is convinced that this is in fact not an advance but a retrogression, for in Aquinas "the radical dichotomy between nature and grace established by Augustine is really set aside by Aquinas. Redemption seems more a supplementation of creation, not its transformed restoration." ${ }^{13}$ In any case, the argumentation is scholastic, rather than biblical, utilizing Aristotelian causality. 
If that had settled the problem we would not have had the fierce debate between Luther and Erasmus concerning the bondage of the will in the sixteenth century. Erasmus, the Roman Catholic humanist, upon hearing that Luther had denied "free choice" (liberum arbitrium, often translated as "free will"), responded in 1524 with A Diatribe or Discourse on the Freedom of the Will [Choice]. The debate that followed was extremely acrimonious with Luther stating, "I wish the defenders of free choice would take warning at this point and realize that when they assert free choice they are denying Christ."14 In this treatise Luther also affirms double predestination as strongly as Augustine or Calvin-an embarrassment to most later Lutherans.

Calvin's discussion of the bondage/freedom of the will issue doesn't go much beyond Augustine and Luther except that it is more nuanced. His position is stated forthrightly in the title of Chapter 2 (of Book II) of the Institutes: "Man Has Now Been Deprived of Freedom of Choice and Bound Over to Miserable Servitude." ${ }^{15}$ The recurring question is whether unregenerate persons can be held responsible for either accepting or rejecting the gospel if their wills are incapable of any good. It is interesting that unlike Luther, Calvin does not discuss predestination in this context. That is taken up later in Book III of the Institutes in the context of faith.

In response to this question Calvin sounds very much like Augustine. "Because of the bondage of sin by which the will is bound," Calvin says,

it cannot move toward good, much less apply itself thereto; for a movement of this sort is the beginning of conversion to God, which in Scripture is ascribed entirely to God's grace ... Therefore, simply to will is of man; to will ill of a corrupt nature, to will well of grace. ${ }^{16}$

Calvin admits that this is "a hard saying" (apparently from Bernard of Clairvaux), but says that it shouldn't be a problem for those who understand the difference between necessity and compulsion. Augustine and Luther had made this distinction before him and Jonathan Edwards was to use it later in his major work, The Freedom of the Will (which, in Augustinian fashion, he denies). That is, to do something of necessity does not mean that we do it because of external, forced compulsion. He appeals to Philippians 1:6-"that he who began a good work in you will bring it to completion on the day of Jesus Christ" - and explains that this denotes the conversion of the will where

God begins his good work in us by arousing love and desire and zeal for righteousness in our hearts; or to speak more correctly, by bending, forming, and directing, our hearts to righteousness. ${ }^{17}$

How does God do this? By his grace and the regenerating work of the Holy Spirit. "The will is not effaced." Rather, "it is created anew; not that the will now begins to exist, but that it is changed from an evil to a good will." And this is "wholly of God's doing . . . it is the work of grace above."18 In short, we will as God wills in us. The clue is the gracious work of the Holy Spirit, who not only actuates our wills but continues to guide and assist them. On the basis of Ezekiel 36:26, which refers to our hearts of stone being transformed into hearts of flesh, Calvin concludes that "our conversion is the creation of a new spirit and a new heart"19 by the Holy Spirit. This means that "the Lord by his Spirit directs, bends, and governs our heart and reigns in it as his own possession." 20 
Much the same approach is taken by the authors of two classic seventeenth century documents, the Canons of Dort (1618-19) and the Westminster Confession (1646). These confessions are often maligned as examples of seventeenth century scholastic orthodoxy. It is true that in the Westminster Confession in particular there is an emphasis on the decrees of God and the introduction of a covenant of works not found in Calvin. Yet, here too we do not have some kind of fatalistic determination but rather an acknowledgment that although our salvation is totally a matter of God's grace-a very biblical notion; see Romans 3:24 and Ephesians 2:8-it does not reduce us to automatons. Somehow God's grace and our response are coordinated through the mysterious working of the Spirit. Note how the Westminster Confession handles effectual calling in Chapter X:

1. All those whom God hath predestined unto life, and those only, he is pleased, in his appointed and accepted time, effectually to call by his Word and Spirit, out of that state of sin and death in which they are by nature, to grace and salvation by Jesus Christ: enlightening their minds, spiritually and savingly, to understand the things of God, taking away their heart of stone, and giving unto them an heart of flesh; renewing their wills, and by his almighty power determining them to that which is good; and effectually drawing them to Jesus Christ; yet so as they come most freely, being made willing by his grace.

2. This effectual call is of God's free and special grace alone, not from anything at all foreseen in man, who is altogether passive therein, until, being quickened and renewed by the Holy Spirit, he is thereby enabled to answer this call, and to embrace the grace offered and conveyed in it. ${ }^{21}$

The allusion to the predestined will be a stumbling block to some people, but they must then deal not only with the Westminster Confession but also with the Apostle Paul in Romans 8-11. The Canons of Dort, on the other hand, which contain an equally strong emphasis on election (and reprobation), do not mention predestination in their discussion of conversion. In articles 11 and 12 of the Third and Fourth Heads of Doctrine there are eloquent descriptions of how regeneration and conversion take place. Here there is no trace of the scholastic type of argumentation one finds in Aquinas or some seventeenth century theologians. Also, contrary to popular opinion, the Canons do not represent a radical departure from the doctrine of grace found in the sixteenth century Reformed Confessions. As the University of Stellenbosch theologian Dirkie Smit points out,

The Canons of Dordrecht did not merely repeat the salvation by grace teachings of the Confessio Belgica and the Heidelberg Catechism, although it in no way wanted to contradict these two confessional documents, but found it imperative precisely to confess this same faith, if possible clearer than before and to articulate possible misunderstandings, confusion and mistaken opinions more clearly than before. ${ }^{22}$

Because of the general unfamiliarity of most people even within the Reformed tradition with the Canons, extensive quotations are appropriate.

When God carries out this good pleasure in his chosen ones, or works true conversion in them, he not only sees to it that the gospel is proclaimed to them outwardly, and enlightens 
their minds powerfully by the Holy Spirit so that they may rightly understand and discern the things of the Spirit of God, but, by the effective operation of the same regenerating Spirit, he also penetrates into the inmost being of man, opens the closed heart, softens the hard heart, and circumcises the heart that is uncircumcised. He infuses new qualities into the will, making the dead will alive, the evil one good, the unwilling one willing, and the stubborn one compliant; he activates and strengthens the will so that, like a good tree, it may be enabled to produce the fruits of good deeds (Article 11). ${ }^{23}$

Here the work of the Holy Spirit is prominent and is the presupposition of the next article which speaks of the miraculous nature of regeneration. Note again the reference to the will at the conclusion of the article.

And this is the regeneration, the new creation, the raising from the dead, and the making alive so clearly proclaimed in the Scriptures, which God works in us without our help. . . . it is an entirely supernatural work, one that is at the same time most powerful and most pleasing, a marvellous, hidden, and inexpressible work, which is not lesser than or inferior in power to that of creation or of raising the dead. . . . And then the will now renewed, is not only activated and motivated by God but in being activated by God is also itself active. For this reason, man himself, by that grace which he has received, is also rightly said to believe and repent (Article 12).

Article 13 is brief and speaks of the mysterious nature of this grace of God whereas Article 14 alludes to Philippians 2:13 and concludes that God "produces the will to believe and the act of believing also." One might conclude from these passages that the human will plays no role at all in one's salvation and is entirely passive. But article 16 tries to correct such a misunderstanding by affirming that

this divine grace of regeneration does not act in people as if they were blocks and stones; nor does it abolish the will and its properties or coerce a reluctant will by force, but spiritually revives, heals, reforms, and-in a manner at once pleasing and powerful-bends it back. As a result, a ready and sincere obedience of the Spirit now begins to prevail where before the rebellion and resistance of the flesh were completely dominant. It is in this that the true and spiritual restoration and freedom of our will consists.

I find this analysis more moving and persuasive than anything cited heretofore. From a Reformed perspective this may appear to settle the matter. God's sovereign grace by means of the mysterious working of the Holy Spirit not only brings about the miraculous experience of the new birth (regeneration) but also enables the believer to respond in repentance and faith. In short, "While God's grace does not bludgeon humanity into salvation - for that would not be love in action - at the same time, unless God takes the initiative and awakens faith in us, we cannot receive God's saving grace." ${ }^{24}$ However, to Wesleyans and others not sympathetic to the Augustinian approach - developed and refined by Luther, Calvin, and later Calvinists - it may appear that the accent still falls too heavily on God and little credence is given to human freedom and responsibility. As a Reformed theologian I want to take seriously their concerns and, if possible, do justice to their objections.

Here I find a passage of Jonathan Edwards, tucked away in one of his occasional writings, that 
seeks to do justice to both sides of the question. Edwards is well known for his classic work on this issue, The Freedom of the Will, ${ }^{25}$ in which he attacks not his contemporary, John Wesley, but various strains of American Arminianism, beginning with his own cousin Solomon Williams. The Freedom of the Will, however, is a difficult philosophical work and cannot even be summarized easily. One should rather turn to Edwards' sermons, the subject of many of them being "the doctrine of God's absolute sovereignty with regard to the salvation of sinners," a theme he pointed out, that was "more remarkably blessed than any other." 26

It is in a later treatise, published posthumously, however, where Edwards takes a position that I find remarkably balanced and different from anything we have encountered before.

In efficacious grace we are not merely passive, nor yet does God do some, and we do the rest. But God does all, and we do all. God produces all, and we act all. For that is what he produces, viz., our own acts. God is the only proper author and fountain; we only are the proper actors. We are, in different respects, wholly passive, and wholly active.

In the Scriptures the same things are represented as from God and from us. God is said to convert, and men are said to convert and turn. God makes a new heart, and we are commanded to circumcise our own hearts; not merely because we must use the means in order to the effect, but the effect itself is our act and our duty. These things are agreeable to that text, "God worketh in you both to will and to do" (Phil. 2:13). ${ }^{27}$

What Edwards is saying here is that our salvation is not a $50-50$ matter, that is, that God takes us so far and then it is up to us (the Arminian understanding), or a 100-0 matter, that is, that salvation is exclusively a result of God's sovereignty or election and we have no responsibility (the perceived Calvinist view). Rather, it is totally a result of God's sovereign grace, and yet we are totally involved. Here one must be careful with a popular passage, Philippians 2:12-13, of which Edwards quoted only the last half; for as New Testament scholars point out, verse 12"Work out your own salvation with fear and trembling" - does not mean that we are to earn our salvation by works. Rather, Paul is pointing out "how saved people live out their salvation in the context of the believing community and the world." ${ }^{28}$ They-and we-"must 'work out' what God in his grace has 'worked in.' So divine sovereignty and human responsibility time and again meet each other in the life of the redeemed." 29

\section{SCRIPTURE AND EXPERIENCE}

This is an important insight, for in Scripture it is not either/or, i.e., either God's sovereign grace or our individual efforts. It is both/and, i.e., wholly a matter of God's grace and our effort. In the Arminian-Calvinist conflicts too often the two have been pitted against each other. ${ }^{30}$ But as the Apostle Paul testifies in reflecting on his own ministry, it is only by God's grace that we can do any good and yet we are totally responsible for our actions.

For I am the least of the apostles, unfit to be called an apostle, because I persecuted the church of God. But by the grace of God I am what I am, and his grace toward me has not been in vain. On the contrary, I worked harder than any of them-though it was not I, but the grace of God that is with me (1 Corinthians 15:9-10; cf. Gal. 1:15 and Eph. 3:7-8).

Here the divine and human dimensions of salvation coalesce in such a way that the integrity of neither is compromised or sacrificed. For the Apostle Paul this coalescence of grace and effort, 
divine sovereignty and human freedom were not perceived as paradoxical but as part and parcel of the same experience of faith. Note how the two are conjoined in his testimony in Galatians 2:20: "I have been crucified with Christ; and it is no longer I who live but it is Christ who lives in me. And the life I now live in the flesh I live by faith in the Son of God, who loved me and gave himself for me."

The Spirit is not mentioned here, but as noted earlier, this is a crucial factor in understanding how God's grace is at work in our lives. As we see in Paul's letter to the Romans, God's gracious activity in our salvation is highlighted in chapters 3-7 with few references to the Holy Spirit and then suddenly in Romans 8 our life in Christ is described almost exclusively in terms of the Spirit. For it is "the law of the Spirit of life in Christ Jesus [who] has set [us] free from the law of sin and death" (8:2). The new life we have in Christ is from beginning to end a gift of God's grace effected by the life-giving Spirit.

This coalescence of God's grace and human effort is frequently experienced by Christians. We make decisions, seeking for God's will through prayer and the counsel of fellow believers, but we are not always sure that the decision is according to God's will; and sometimes we make bad decisions. Yet in and through it all God's will is eventually done. We are not always aware of God's Spirit working in our lives but in retrospect we see how God led and guided us in ways that we couldn't have foreseen. Believers whose lives have been marked by frequent disappointments or great suffering may have more difficulty in appreciating this; and yet the testimony of countless saints of God is that even in the midst of suffering and loss they can still testify to the riches of God's amazing grace. With the Apostle Paul they can affirm with confidence, "We know that all things work together for good for those who love God, who are called according to his purpose" (Romans 8:28).

What I have been trying to say has been expressed eloquently in a hymn by an unknown writer:

I sought the Lord, and afterward I knew he moved my soul to seek him, seeking me; it was not I that found, O Savior true; no, I was found of thee.

Thou didst reach forth thy hand and mine enfold; I walked and sank not on the storm-vexed sea; 'twas not so much that love on thee took hold as thou, dear Lord, on me. ${ }^{31}$

\section{(ENDNOTES)}

1 Theology in the Wesleyan Spirit (Nashville: Discipleship Resources, 1975), 15.

2 On this issue see Thomas F. Torrance's The Doctrine of Grace in the Apostolic Fathers (Grand Rapids: Eerdmans, 1959). His conclusion: "Grace by its very nature, in the thought of the New Testament, must be the absolutely predominant factor in faith, else it is not grace. In the Apostolic Fathers it did not have that radical character . . . . what took absolute precedence [for them] was God's call to a new life in obedience to revealed truth," 133.

3 A key work here is Augustine's De libero arbitrio (On Free Will), consisting of three books, the first begun in 387, the last completed in 395.

4 John Burnaby. Introduction to The Spirit and the Letter in Augustine: Later Works, Library of Christian Classics, Vol. VIII (Philadelphia: Westminster, 1955), 192.

5 Cited in Jaroslav Pelikan, The Growth of Medieval Theology (600-1300), Vol. 3 in "The 
Christian Tradition" (Chicago: University of Chicago Press, 1978), 81.

6 Cited in Pelikan, op. cit., 273. The question of God's relation to time and eternity is currently under review. See, e.g., the symposium God and Time. Four View, by Paul Helm, Alan G.

Padgett, William Lane Craig, and Nicholas Wolterstorff (Downers Grove, IL: InterVarsity Press, 2001).

7 Summa Theologica I.83.1, in the Summa of the Summa edition edited by Peter Kreeft (San

Francisco: Ignatius Press, 1990), 297.

8 Ibid., note 49.

9 Summa I.83.1; Kreeft 298.

10 Ibid.

11 Ibid.

12 Op. cit., 299, note 50.

13 History of Christianity in the Middle Ages (Nashville: Abingdon, 1960), 259.

14 The Bondage of the Will, in Luther and Erasmus: Free Will and Salvation, edited by E.

Gordon Rupp and Philip S. Watson. Library of Christian Classics Vol. XVII (Philadelphia:

Westminster Press, 1969), 321.

15 All quotations from the Institutes are from the Library of Christian Classics edition, edited by John T. McNeill and translated by Ford Lewis Battles (Philadelphia: Westminster Press, 1961).

16 Institutes II.3.5.

17 Institutes II.3.6.

18 Ibid. In this connection Calvin cites Ezekiel 36:26-7; 2 Corinthians 3:5; Philippians 2:13, and 1 Corinthians 12:6.

19 Institutes II.3.8.

20 Institutes II.3.10. Space limitations do not allow for a discussion of Calvin's major treatment of this subject: The Bondage and Liberation of the Will. A Defense of the Orthodox Doctrine of Human Choice Against Pighius. This has finally come out in an English translation by G. I. Davies, edited by A. N. S. Lane (Grand Rapids: Baker Books, 1996).

21 The American Presbyterians, both north and south, at different points in their history felt that the Westminster Confession was lacking in its treatment of the Holy Spirit. Consequently, in 1903 a new chapter was added: "Of the Holy Spirit," which was inserted as Chapter IX in the PCUS version and Chapter XXIV in the UPUSA version. See The Book of Confessions published by the office of the General Assembly of the Presbyterian Church U.S.A., 1996.

22 "Confessing as gathering the fragments?" in Essays on Being Reformed. Collected Essays 3 (SUN MeDIA Stellenbosch, 2009), 301.

23 I am using the translation found in Ecumenical Creeds and Reformed Confessions (Grand Rapids: Board of Publications of the Christian Reformed Church, 1988).

24 John W. De Gruchy, John Calvin. Christian Humanist \& Evangelical Reformer (Wellington, S.A.: Lux Verbi BM, 2009), 174.

25 The best edition of this classic is that edited by Paul Ramsey in the Yale University series (New Haven: Yale U. Press, 1957).

26 A Narrative of Surprising Conversions, in Select Works of Jonathan Edwards, Vol. I (London: Banner of Truth, 1965), 31.

27 Works of President Edwards Vol. II (reprint of the Worcester Edition), 580. Conrad Cherry quotes this passage and adds: "There is a necessary connection between divine grace and human act, but it is a question of moral not natural necessity. Rather than being an external force which moves man's faith as a lifeless object, grace is the divine gift which operates within the living, willing human subject," The Theology of Jonathan Edwards. A Reappraisal (Bloomington and 
Indianapolis: Indiana U. Press, 1990), 195.

28 Gordon D. Fee, Paul's Letter to the Philippians (Grand Rapids: Eerdmans, 1995), 235.

29 Jac. J. Müller, The Epistles of Paul to the Philippians and to Philemon (Grand Rapids: Eerdmans, 1995), 91.

30 J. I. Packer, in his little classic, Evangelism and the Sovereignty of God (Chicago: InterVarsity Press, 1961), also seeks to do justice to both sides of this issue, although he, too, is a staunch Calvinist. As he points out, “God's sovereignty and man's responsibility are taught side by side in the same Bible, sometimes, indeed, in the same text." (He cites Luke 22:22 and Acts $2: 23$ as examples.) "God's sovereignty is a reality, and man's responsibility is a reality too" (22-3). However, where Packer prefers to speak of this question in terms of "antinomy," (24f.), I prefer to think of sovereign grace and human freedom as coalescing. This, it seems to me, is the message of Scripture which is often confirmed by human experience. Lest it seem un-Reformed to appeal to human experience (usually a Wesleyan approach), I would remind the reader that Calvin frequently speaks like this: "As Scripture teaches us . . . and is confirmed by human experience ...." See, e.g. Institutes I.10.2, I.13.14. As Willem Balke rightly notes, however, "Experience is never a priori, always a posteriore. Experientia is born of faith in the Word and experience afterward establishes the trustworthiness of the Word." "The Word of God and Experientia according to Calvin," in Calvinus Ecclesiae Doctor, hrsg. von W. H. Neuser (Kampen, the Netherlands:

J. H. Kok B.V., 1980), 25. Moreover, I place more emphasis on the role of the Holy Spirit in regard to this matter than Packer.

31 Rejoice in the Lord, edited by Erik Routley (Grand Rapids: Eerdmans, 1985), \#162. 